\title{
Morphological changes induced in the antenna of cowpea beetle, Callosobruchus maculatus (Fabricius) (Coleoptera : Bruchidae) after treatment with lufenuron
}

\author{
Soryia, E. Hafez; Ragaa, K.A. Hamed and Laila, S. Hamouda \\ Department of Entomology, Faculty of Science, Ain Shams Univeristy.
}

\section{ABSTRACT}

The effect of a chitin synthesis inhibitor (Lufenuron) on the antennal segements and their sensilla of cowpea beetle, Callosobruchus maculatus (Fabricius) was studied by using scanning electron microscope.

Seven types of sensilla were recognized on both untreated and treated antennae with $9 \mathrm{ppm}$ of lufenuron, including Böhm bristles (BB), two types of sensilla trichodea $\left(\mathrm{ST}_{1}, \mathrm{ST}_{2}\right)$, sensilla chaetica $(\mathrm{SC})$, two types of sensilla basiconica $\left(\mathrm{SB}_{1}\right.$, $\mathrm{SB}_{2}$ ) and grooved peg (GP). The functions of these sensilla were discussed in relation to their position on the antenna.

Significant difference in lengths of most segments of the antennae between untreated and treated beetles was observed. A significant difference in lengths and diameters of nearly all types of sensilla was recorded. The highest increase in length of sensilla was noticed for the sensilla chaetica followed by sensilla trichodea. These types are used by insects as mechanosensory, sex pheromone and gustatory receptors that help them to make a decision to select their food and oviposition sites.

Keywords: Cowpea beetle, Callosobruchus maculatus, antennal sensilla, insect growth regulator, scanning electron microscope (SEM).

\section{INTRODUCTION}

Callosobruchus maculatus is a cosmopolitan pest of stored grain legumes (Fabaceae) particularly of the genus Vigna (Cope and Fox, 2003). As a consequence of infestation, seed lots become warm resulting in quality loss and mould growth (Rees, 2004). Damaged seeds are unsuitable for human consumption, and cannot be used for agricultural and commercial purposes.

Searching for new effective pest control agents, much attention has been focused on compounds which disrupt the normal process of insect development. Insect growth inhibitors, in contrast to traditional insecticides are generally non to slightly toxic to higher animals. They inhibit the synthesis of chitin of insects by causing abnormal endocuticular deposition and absorptive moulting (Post and Vincent, 1973). Lufenuron (chitin synthesis inhibitor) is one of the most newly introduced synthetic insect growth regulators. It is used for controlling lepidopterous and Coleopterous larvae on cotton, maize, vegetables, citrus white fly and rust mites on citrus fruits.

Insects antennae are mobile, segmented, paired head appendages and are found in nearly all insects groups (Gullan and Granston, 1994). Numerous sensory-organs or sensilla occur on antennae in the form of hairs, pegs, pits or cones.

Several studies have characterized the antennal sensilla of various species of beetles using electron microscopic techniques (Jourdan et al., 1995 and Said et al., 2003). However, very few of such studies have focused on Bruchidae. Thus, the aim of this work is to describe the sensilla and to study the effect of Lufenuron on the different types of antennal sensilla of Callosobruchus maculatus. 


\section{MATERIALS AND METHODS}

The cowpea beetle, Callosobruchus maculatus (Fabricius) used in the present investigation was obtained from the Plant Protection Center, at Dokki, Giza. Insects were reared in $500 \mathrm{ml}$ glass jars which contained a suitable number of cowpea grains. The jars were covered with muslin secured by rubber bands and were introduced in an incubator for rearing at $27^{\circ} \mathrm{C}$ and $75 \pm 2 \% \mathrm{RH}$.

The morphology and distribution of various types of antennal sensilla in untreated and $F_{1}$ adults of Callosobruchus maculatus resulting from adults treated with 9 ppm Lufenuron were studied by using scanning electron microscope.

The antennae of adults of both untreated and treated groups were separately fixed in a solution of $2.5 \%$ glutaraldehyde, and kept over night at $4 \mathrm{C}$.Then they were rinsed in a phosphate buffer $\mathrm{pH}$ (7.2) three times for $15 \mathrm{~min}$, subjected to postfixation in $1 \%$ osmium tetraoxide for $2 \mathrm{hr}$, bathed three times for $15 \mathrm{~min}$ in phosphate buffer. Finally, They were dehydrated in 30, 50, 70, 90 and 100\% ethanol (three times) and each for $15 \mathrm{~min}$. Afterwards, they were dried and finally coated with gold using sputter coating for examination by using scanning electron microscope (SEM) JEOL, JSM 5300.

\section{Statistical analysis:}

In classifying sensilla, the terminology of Schneider (1964) and Zacharuck (1985) was applied, measurements $(\mu \mathrm{m})$ were obtained from photomicrographs of at least 5 individuals. The data obtained were analyzed using t-test with SPSS 10.0 for windows to determine any significant difference $(\mathrm{p}<0.05)$.

\section{RESULTS}

The antennae of Callosobruchus maculatus is serrate in shape. It consists of a scape, pedicel and nine-segmented flagellum as shown in Fig. (1). All flagellomeres, except for the first one, have acute-angled wedge-shaped ventral extensions, where most types of the sensilla are located. However, the antennomeres vary markedly in size and length (Table 1).

Treatment with 9 ppm Lufenuron led to losing of the above mentioned serrate shape of antenna. In addition, the lengths of scape, pedicel, first, second and fifth segments of flagellum became significantly shorter than those for the control ones. The highest decrease was recorded for the first flagellar segment where the length of segment was $0.04 \pm 0.002 \mathrm{~mm}$ compared with $0.10 \pm 0.002 \mathrm{~mm}$ for the control ones. On the other hand, sixth, eighth and ninth segments of flagellum became longer than those of the untreated ones. Their mean lengths were $0.14 \pm 0.002,0.14 \pm 0.001$ and $0.18 \pm 0.002 \mathrm{~mm}$ compared to $0.12 \pm 0.002,0.12 \pm 0.001$ and $0.16 \pm 0.002$ for the control ones. 
Table (1): Mean lengths (mm) of antennal segments of untreated and treated adult of Callosobruchus maculatus with Lufenuron.

\begin{tabular}{|c|c|c|}
\hline \multirow{2}{*}{ Segments } & Untreated & Treated \\
\cline { 2 - 3 } & Mean length \pm SE $(\mathbf{m m})$ & Mean length \pm SE $(\mathbf{m m})$ \\
\hline Scape & $0.14 \pm 0.002$ & $0.10 \pm 0.002$ \\
\hline Pedicel & $0.08 \pm 0.002$ & $0.06 \pm 0.002$ \\
\hline$F_{1}$ & $0.10 \pm 0.002$ & $0.04 \pm 0.002$ \\
\hline$F_{2}$ & $0.14 \pm 0.004$ & $0.12 \pm 0.002$ \\
\hline$F_{3}$ & $0.14 \pm 0.002$ & $0.14 \pm 0.002$ \\
\hline$F_{4}$ & $0.14 \pm 0.002$ & $0.14 \pm 0.002$ \\
\hline$F_{5}$ & $0.14 \pm 0.001$ & $0.12 \pm 0.002$ \\
\hline$F_{6}$ & $0.12 \pm 0.002$ & $0.14 \pm 0.002$ \\
\hline$F_{7}$ & $0.12 \pm 0.003$ & $0.12 \pm 0.002$ \\
\hline$F_{8}$ & $0.12 \pm 0.001$ & $0.14 \pm 0.001$ \\
\hline$F_{9}$ & $0.16 \pm 0.002$ & $0.18 \pm 0.002$ \\
\hline Total & 1.4 & 1.3 \\
\hline
\end{tabular}

$(n=5)$.

Table (2) : Mean lengths of the measured sensilla of untreated and treated adult of Callosobruchus maculatus with Lufenuron

\begin{tabular}{|c|c|c|c|c|}
\hline \multirow[b]{2}{*}{ Sensilla types } & \multicolumn{2}{|c|}{ Untreated antenna } & \multicolumn{2}{|c|}{ Treated antenna } \\
\hline & $\begin{array}{c}\text { Mean length } \\
(\mu \mathrm{m}) \pm \mathrm{SE}\end{array}$ & Diameter $\pm \mathrm{SE}$ & $\begin{array}{c}\text { Mean length } \\
(\mu \mathrm{m}) \pm \mathrm{SE}\end{array}$ & Diameter $\pm \mathrm{SE}$ \\
\hline BB Böhmbristle & $1.9 \pm 0.1$ & $0.3 \pm 0.08$ & $1.7 \pm 0.1$ & $0.3 \pm 0.1$ \\
\hline $\mathrm{St}_{1}$ sensilla trichodea 1 & $10.1 \pm 0.8$ & $0.5 \pm 0.2$ & $15.2 \pm 2.5$ & $0.4 \pm 0.1$ \\
\hline $\mathrm{St}_{2}$ sensilla trichodea 2 & $7.1 \pm 1.0$ & $0.5 \pm 0.2$ & $7.3 \pm 1.0$ & $0.9 \pm 0.3$ \\
\hline $\mathrm{Sb}_{1}$ sensilla basiconica 1 & $5.9 \pm 1.2$ & $0.9 \pm 0.4$ & $6.1 \pm 1.2$ & $0.7 \pm 0.1$ \\
\hline $\mathrm{Sb}_{2}$ sensilla basiconica 2 & $1.7 \pm 0.5$ & $0.6 \pm 0.1$ & $3 \pm 0.4$ & $0.9 \pm 0.1$ \\
\hline Sc sensilla chaetica & $10 \pm 2.6$ & $1.0 \pm 0.4$ & $16.4 \pm 0.9$ & $1.0 \pm 0.1$ \\
\hline
\end{tabular}

\section{Antennal sensilla types:}

Based on size, shape, distribution and cuticular attachment. Seven types of sensilla were recognized on both untreated and treated adult antennae of Callosobruchus maculatus. The sensilla are one type of Böhm bristles (BB), two types of sensilla trichodea $\left(\mathrm{ST}_{1}, \mathrm{ST}_{2}\right)$, one type of sensilla chaetica $(\mathrm{SC})$, two types of sensilla basiconica $\left(\mathrm{SB}_{1}, \mathrm{SB}_{2}\right)$ and one type of grooved peg (GP). The characteristic morpholgocial features of the antennal sensilla in untreated and treated Callosobruchus maculatus are shown in figs. (1-10) and Table (2).

\section{1- Böhm bristles (BB):}

Each sensillum is a triangular peg- like structure that tapers to a blunt apex. They are inserted into a wide sockets (Figs 5,6). The BB is short having a mean length and diameter of $1.9 \pm 0.1$ and $0.3 \pm 0.08 \mu \mathrm{m}$, respectively compared with $1.7 \pm 0.1$ and $0.3 \pm 0.1 \mu \mathrm{m}$, respectively for the treated ones (Table 2). The BB sensilla occur on the base of the scape and pedicel at the joints between the scape and the head and between the scape and the pedicel.

\section{2- Sensilla trichodea $1\left(\mathrm{ST}_{1}\right)$ :}

The $\mathrm{ST}_{1}$ sensilla are sharp-tipped hairs and are nearly straight or slightly curved.The hair bases inserted tightly into a small cuticular socket (Figs.3,4,5,6,7,8,9 and 10a,b). They have a mean length and diameter of $10.1 \pm 0.8$ and $0.5 \pm 0.2 \mu \mathrm{m}$, respectively compared with $15.2 \pm 2.5$ and $0.4 \pm 0.1 \mu \mathrm{m}$, respectively for the treated ones (Table 2). Fusion of some sensilla was noticed in treated ones (Fig. 6). The $\mathrm{ST}_{1}$ is the most abundant sensilla type on the whole antenna.

\section{3- Sensilla Trichodea $2\left(\mathrm{ST}_{2}\right)$ :}

The $\mathrm{ST}_{2}$ sensilla are blunt-tipped straight hairs. They are located tightly in a small socket among $\mathrm{ST}_{1}$ (Figs. 3, 7). They have a mean length and diameter of 
$7.1 \pm 1.0$ and $0.5 \pm 0.2 \mu \mathrm{m}$, respectively compared with $7.3 \pm 1.0$ and $0.9 \pm 0.3 \mu \mathrm{m}$, respectivelyfor the treated ones (Table 2).

4- Sensilla basiconica $1\left(\mathrm{SB}_{1}\right)$ :

The $\mathrm{SB}_{1}$ are characterized by a straightly blunt Tip. They are set into a tight socket (Figs. 7,8,10a,b). They have a mean length and diameter of $5.9 \pm 1.2$ and $0.9 \pm$ $0.4 \mu \mathrm{m}$, respectively compared with $6.1 \pm 1.2$ and $0.7 \pm 0.1 \mu \mathrm{m}$, respectively for the treated ones (Table 2). Most of the sensilla of this type are located on the lateral side of the flagellar segments except the first and second segments.

\section{5- Sensilla basiconica $2\left(\mathbf{S B}_{2}\right)$ :}

$\mathrm{SB}_{2}$ are characterized by a blunt tip which curved at the distal end. They are inserted into wide sockets (figs.7,8,10a,b). They are short having a mean length and width of $1.7 \pm 0.5$ and $0.6 \pm 0.1 \mu \mathrm{m}$, respectively compared with $3 \pm 0.4$ and $0.9 \pm 0.1$ $\mu \mathrm{m}$, respectively for the treated ones (Table 2).

In addition, some pores appeared in treated sensilla (fig.10 b). The distribution of this type of sensilla likes that of the above mentioned type.

\section{6- Sensilla Chaetica (SC):}

SC are straight hairs with blunt tips. They are inserted into a wide socket (fig. $10 \mathrm{a} \& \mathrm{~b}$ ). The sensilla had a mean length and width of $10 \pm 2.6$ and $1.0 \pm 0.4 \mu \mathrm{m}$, respectively compared with $16.4 \pm 0.9$ and $1.0 \pm 0.1 \mu \mathrm{m}$, respectively for treated ones. They occur on each antennomere of the antennae.

\section{7- Grooved pegs (GP):}

This type of sensilla is characterized by grooved surface and straight pegs with blunt tip (Figs.6,7). GP are bulb-like structures projecting from a depression in the center of raised area of cuticle. An accurate measurement of sensillum length could not be made.

From the above mention types, table (2) showed a significant difference between the lengths and diameter of most types of sensilla on the untreated and treated antennae in this study.

\section{DISCUSSION}

The general structure of the antenna of Callosobruchus maculatus is similar to that in other beetle species (Barlin and Vinson, 1981; Ritcey and Mclver, 1990; Skilbeck and Anderson, 1996; Merivee et al., 1999, 2001; Said et al., 2003 and $\mathrm{Hu}$ et al., 2009).

Observations of SEM illustrate that the antennal morphology and sensilla of untreated Callosobruchus maculatus and Lufenuron treated have seven different types of antennal sensilla.

Three functional types of insect sensilla have been identified in immature insects, aporous, that are mostly mechanosensilla, but include many thermohygrosensilla; uniporous that may be gustatory chemosensilla or chemomechanosensilla and mutliporous, olfactory chemosensilla (Altner, 1977 and Zacharuk, 1980). The sensilla of insects consists of a specialized sensory cuticle innervated by the dendrites of one or more sensory neurons and usually three or four accessory cells that ensheath the neurons and associated sinuses (Zacharuk, 1985).

The Böhm bristles sensilla (BB) described in the current study are similar to the sensilla (Hair plate sensilla) on the antennae of the cabbage stem flea beetle Psylliodes chrysocephala (Bartler et al., 1999); the click beetles Limonius aeruginosus (Merivee et al., 1998); Bembidion properans (Merivee et al., 2002) and (Hu et al., 2009) on bruchid beetles Callosobruchus chinensis and Callosobruchus maculatus the presence 
of the BB on the scape and pedicel suggests that these might be mechanoreceptors (Schneider, 1964 and Zacharuk, 1985). Also, their presence at the intersegemental joints between the scape and head and pedical in other insects, indicates that these sensilla probably perceive the antennal position and movements (Merivee et al., 2002).

Sensilla trichodea $1\left(\mathrm{ST}_{1}\right)$ has been described in different insects as having putative mechanoreceptive functions, such as in the perception of mechanosensory stimuli (Pettersson et al., 2001; Roux et al., 2005 and Onagbola and Fadamiro, 2008).

Keil (1999) cited that trichoid sensilla may be olfactory, but sensilla found on the pedicel are usually mainly mechanoreceptive. Schneider (1964) suggests that trichoid sensilla may be dye-permeable and so may posses chemoreceptivity.

Sensilla Trichodea $2\left(\mathrm{ST}_{2}\right)$ are common on the antennal flagellum of insects. Merivee et al., (1999), suggested that they probably function as sex pheromone receptors. In the ground beetle, Platynus dorsalis (Merivee et al., 2001) it might indicate that these sensilla probably respond to aggregation pheromone.

In the present study, the sensilla chaetica (SC) are found in all parts of the flagella. These observations have been recorded by many authors in other insects (Merivee et al., 1998, 1999, 2002; Said et al., 2003; Roux et al., 2005; Faucheux et al., 2006; Gao et al., 2007 and Onagbola and Fadamiro, 2008). The SC sensilla believed to have a dual function of mechanoreception and contact chemoreception. The lack of wall pores and the presence of a tubular body suggests a combined mechanosensory and gustatory function (Zacharuk, 1980, 1985). Similar gustatory sensilla have been reported in the antennae of several species of beetles including the pine weevil, Hylobius abietis (Mustapara, 1973) and in the saw toothed grain beetle , Oryzaephilus surinamensis (White and Luke, 1986). Antennal tapping of leaf surfaces prior to feeding probably exposes these gustatory sensilla to tactile and chemical stimuli.

The sensilla basiconica $1,2\left(\mathrm{SB}_{1}\right)$ and $\left(\mathrm{SB}_{2}\right)$ resemble the sensilla basiconica type I and type II in the eucalyptus woodborer, Phoracantha semipunctata (Lopes et al., 2002) and to their homologous species which described by $\mathrm{Hu}$ et al. 2009 in Callosobruchus maculatus and Callosobruchus Chinensis. These sensilla may have a sex-pheromone receptor role and olfactory function.

The grooved pegs in Callosobruchus maculatus are similar in shape and small number to the following "sensilla styloconicum in the cigarette beetle Lasioderma serricorne (Okada et al., 1992); sensilla basiconica type IV in Limonius aeruginosus (Merivee et al., 1998) and Basiconica capitate peg sensillum (B.C.P.S) in Liporrhopalum tentacularis (Timothy, 2005). The probable function of these sensilla is chemo-or thermoreception (Zacharuk, 1985).

In thermo-hygrosensilla, the sensory is an aporous peg. The tip of the dendrites of the humidity sensitive neurons are presumed to be the ones that are tightly encased within the peg (Altner and Loftus, 1985). These pegs are usually also thermosensitive.

The present study showed that treatment of adult beetles with 9 ppm of Lufenuron caused abnormalities in the shape of the antennae and the length of sensilla were longer than the untreated one except (BB). Fusion of some sensillae was also observed in treated sensilla trichodea. Besides, some pores appeared in sensilla basiconica .These abnormalities may be attributed to the effect of insect growth regulator indirectly on the release of ecdysteroids, through interfering with the neuroendocrine sites responsible for the release of this hormone. In agreement with Zohry (2008) who revealed that $\mathrm{LC}_{50}$ of flufenoxuron caused the formation of abnormal antennae and affect the length and distribution of the sensilla on Spodoptera 
littoralis. Similarly, Schmutterer et al., (1993) observed morphogenetic defects on antennae due to treatments of nymphs of desert locust, Schistocerca gregaria and the red locust, Nomadacris septemfasciata with neem oil. Also, Akyurtlakli and Karacali (2000) and Hazarika and Baishya (1997), observed malformed antennae on Melanogryllus desertus and Dicla dispa armigera as affected by Juvenile hormone analogue methoprene.

In conclusion, the present study has identified and characterized the different sensillum types on the antenna of Callosobruchus maculatus. At least, two olfactory sensilla, two sex-pheromone receptors, and two chemoreceptors are described on the antennae of untreated and treated beetles with CSI (Lufenuron). Future studies on the functional morphology of the antennal sensilla using (TEM) transmission electron microscopy coupled with electrophysiological recordings must be performed to confirm the function of the different sensilla identified in this study.

\section{REFERENCES}

Akyurtlakli, N. and Karacali, S. (2000). The effects of Juvenile hormone and hormone analogue ZR-512 on egg hatching and embryonic development of Melanogryllus desertus Pall. Turkiye Entomologi Dergisi. 24(2):87-100.

Altner, H. (1977). Insect sensillum specificity and structure: an approach to a new typology. In olfaction and taste VI, ed. J. Le Magnen, P. MacLed, 6: 295 - 303. Washington: Information Retrieval.

Altner, H. and Loftus, R. (1985). Ultrastructure and function of insect thermo and hygroreceptors. Annu. Rev. Entomol. 30: 273-95.

Barlin, M.R. and Vinson, S.B. (1981). Multiporous plate sensilla in antennae of the Chalcidoidae (Hymenoptera). Int. J. Insect Morphol. Embryol. 10: $29-42$.

Bartler, E.; Romani, R.; Williams, I.H. and Isidora, N. (1999). Functional anatomy of sensory structures on the antennae of Psylliodes chrysocephala L. (Coleoptera: Chrysomelidae). Int. J. Insect Morphol. Embryol. 28:291-300.

Cope, J.M. and Fox, C.W. (2003). Oviposition decision in the seed beetle Callosobruchus maculatus (Coleoptera: Bruchidae): effects of seed size on super parasitism. J. stored Prod. Res., 39: 355-365.

Faucheux, M.J.; Kristensen, N.P. and Yen, S.H. (2006). The antennae of neopseustid moths; Morpholgoy and Phylogenetic implications with special reference to the sensilla (Insecta, Lepidoptera, Neopseustidae). Zool. Anz. 245: 131-142.

French, A.S. (1988). Transduction mechanisms of mechanosensilla. Annu. Rev. Entomol. 33: 39-58.

Gao, Y.; Luo, I.Z. and Hammond, A. (2007). Antennal morphology, structure and sensilla distribution in Microplitis pallidipes (Hymenoptera: Braconidae). Micron 38: 684-693.

Gullan, P.J. and Granston, P.S. (1994).The Insects: An Outline of EntomologyChapman \& Hall. London.

Hazarika, L.K. and Baishya, R.L. (1997). Effect of methoprene on the developmental stages of rice hispa. J. Pesticide, 9 (1): 109-112.

Hu, F.; Zhang, G.N. and Wang, J.J. (2009). Scanning electron microscopy studies of antennal sensilla of bruchid beetles, Callosobruchus chinensis (L.) 
amd Callosobruchus maculatus (F.) (Coleoptera: Bruchidae). Micron 40: 320-326.

Jourdan, H.; Barbier, R.; Bernard, J. and Ferran, A. (1995). Antennal sensilla and sexual dimorphism of the adult ladybird beetle, Semiadalia undecimnotata Schn. (Coleoptera: Coccinellidae). Int. J. Insect Morphol. Embryol. 24:307-322.

Keil, T.A. (1999).Morphology and development of the peripheral olfactory organs. In Insect olfaction, pp. 5-47 (ed. B.S. Hansson). Springer, New York.

Lopes, O.; Barata, E.N.; Mustapara, H. and Araujo, J. (2002). Fine structure of antennal sensilla basiconica and their detection of plant volatiles in the eucalyptus woodborer, Pharacantha semipunctata Fabricius (Coleoptera: Cerambycidae). Arthropod Struct. Pev. 31: 1-13.

Merivee, E.; Ploomi, A.; Rahi, M.; Bresciani, J.; Ravn, H.P.; Luik, A. and Sammelseig, V. (2002). Antennal sensilla of the ground beetle Bembidion properans Sleph. (Coleoptera: Carabidae). Micron 33: 429-440.

Merivee, E.; Ploomi, A.; Rahi, M.; Luik, A. and Sammelseig, V. (2001). Antennal sensilla of the ground beetle Platynus dorsalis (Pontoppidan, 1763) (Coleoptera: Carabidae). Microsc. Res. Technol. 55: 339-349.

Merivee, E.; Rahi, M. and Luik, A. (1999). Antennal sensilla of the click beetle, Melanotus villosus (Geoffroy) (Coleoptera: Elateridae). Int. J. Insect Morphol. Embryol. 28:41-51.

Merivee, E.; Rahi, M.; Bresciani, J.; Ravn, H.P. and Luik, A. (1998). Antennal sensilla of the click beetle. Limonius aeruginosus (Olivier) (Coleoptera: Elateridae). Int. J. Insect Morphol. Embryol. 27: 311-318.

Mustaparta, H. (1973). Olfactory sensilla on the antennae of the pine weevil, Hylobius abietis; Z. Zellforsch. Mikrosk. Anat. 144:559-571.

Okada, K.; Mori, M.; Shimazaki, K. and Chuman, T. (1992). Morphological studies on the antennal sensilla of the cigarette beetle, Lasioderma serricorne (F.) (Coleoptera: Anobiidae). Jpn. J. Appl. Entomol. Z 27: 269-276.

Onagbola, E.O. and Fadamiro, H.Y. (2008). Scanning electron microscopy studies of antennal sensilla of Pteromalus cerealellae (Hymenoptera: Pteromalidae). Micron 39:526-535.

Pettersson, E.M.; Hallberg, E. and Birgersson, G. (2001). Evidence for the importance of odour-reception in the parasitoid Rhopalicius tutela (walker) (Hymenoptera: Pteromalidae). Appl. Entomol. 125:293-301.

Post, L.C. and Vincent, W.R. (1973).A new insecticide chitin synthesis. Natur wissenschaften 60: 431- 432.

Rees, D. (2004). Insects of stored products. CSIRO Publishing, Canberra, Australia.

Ritcey, G.M. and Mclver, S.B. (1990). External morphology of antennal sensilla of four species of adult flea beetles (Coleoptera: Chrysomelidae: Alticinae). J. Insect Morphol. Embryol. 19: 141-153.

Roux, O.; Van Baaren, J.; Gers, C.; Arvanitakis, L. and Iegal, I. (2005). Antennal structure and oviposition behaviour of the Plutella xylostella specialist parasitoid Cotesia plutellae. Micro. Res. Technol.68:36-44.

Said, I.; Tauban, D.; Renou, M.; Mori, K. and Rochat, D. (2003). Structure and function of the antennal sensilla of the palm weevil, Rhynchophorus palmarum (Coleoptera: Curculionidae). J. Insect Physiol. 49:857-872.

Schmutterer, H.; Baumgart, M.; Freisewinkel, D.; Langenwald, J. and Nicol, C.M.Y. (1993). The effects of neem oil and other neem products on nymphs 
and resulting adults of Schistocerca gregaria, Nomadacris septemfasciata, Locusta migratoria and Zonocerus variegates. (Bibliographic citation): J. Appl. Entomol., 116(2): 178-186.

Schneider, D. (1964). Insect antennae. Annu. Rev. Entomol. 9:103-122.

Skilbeck, C.A. and Anderson, M. (1996). The ultrastructure, morphology and distribution of sensilla on the antennae of the adult parasitoid Aleochara bilineata Gyll and Aleochara bipustulata L. (Coleoptera: Staphylinidae). Int. J. Insect Morphol. Embryol. 25: 261-280.

Timothy, C. (2005). External morphology of antennal sensilla in relation to the host searching behaviour of Liporrhopalum tentacularis Grandi (Hymenoptera: Agaonidae). PLGY 3040 Project Report.

White, P.R. and Luke, B.M. (1986). Fine structure, function and distribution of antennal sensilla in the saw toothed grain beetle, Oryzaephilus surinamensis: Physiol. Entomol. 11: 227-238.

Zacharuk, R.Y. (1980). Ultrastructure and function of insect chemosensilla; Annu. Rev. Entomol. 25: 27-47.

Zacharuk, R.Y. (1985). Antennae and sensillaL: In Comprehensive Insect Physiology, Biochemistry and Pharmacology (Eds. Kerkut, G. A. and Gilbert, L. I) Oxford pergamon press, Vol. 6: 1-69.

Zohry, N.M.H. (2008). Effect of flufenoxuron on the antennal sensilla of Spodoptera littoralis (Lepidoptera: Noctuidae). Egypt. Acad. J. Biol. Sci., 1(2): 13-25. 


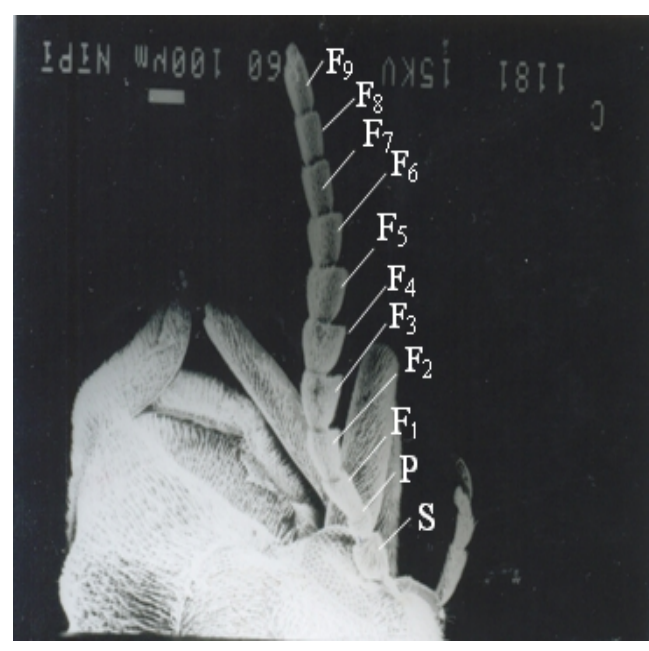

Fig. (1): SEM photomicrograph of untreated adult, Callosobruchus maculatus showing parts of the antenna: Scape $(\mathrm{S})$, Pedicel $(\mathrm{P})$ and nine flagellar segments $\left(\mathrm{F}_{1}-\mathrm{F}_{9}\right)$. Bar $100 \mu \mathrm{m}$.

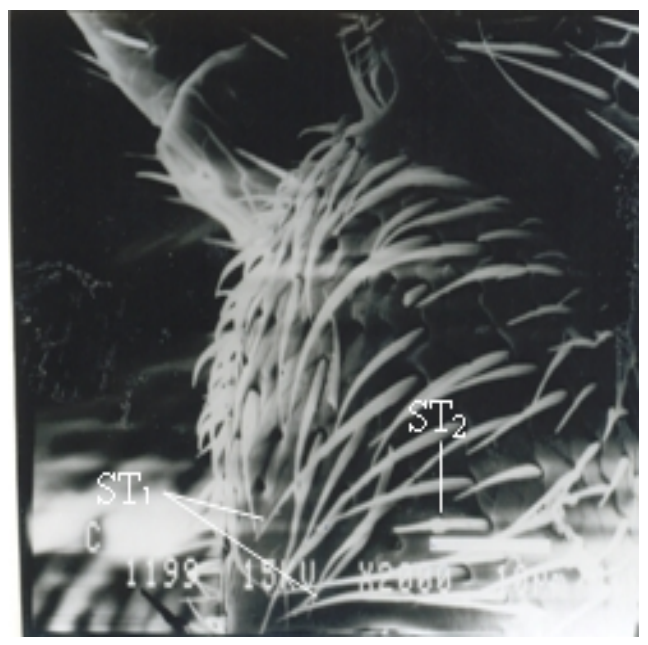

Fig. (3): SEM photomicrograph of untreated adult of Callosobruchus maculatus in scape region showing sensilla trichodea $\left(\mathrm{ST}_{1}\right.$ and $\left.\mathrm{ST}_{2}\right)$. Bar $100 \mu \mathrm{m}$.

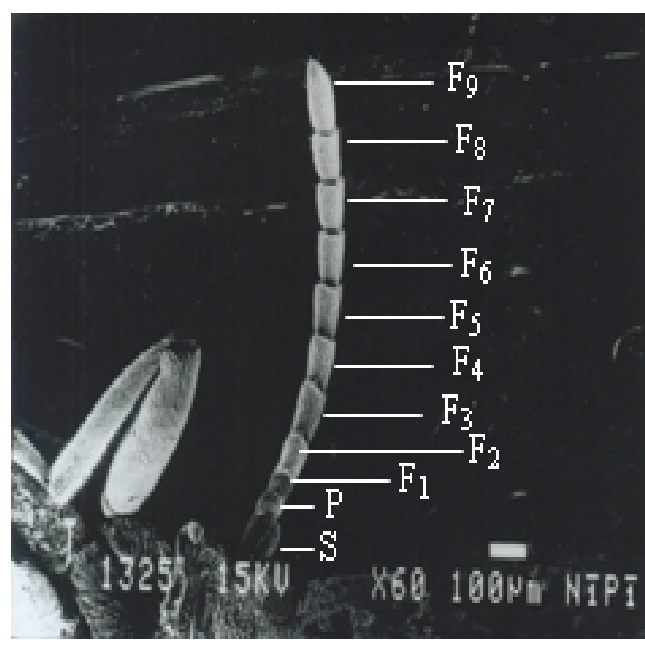

Fig. (2): SEM photomicrograph of treated adult of Callosobruchus maculatus with Lufenuron showing parts of the antenna: Scape (S), Pedicel $(\mathrm{P})$ nine flagellar segments $\left(\mathrm{F}_{1}-\mathrm{F}_{9}\right)$. Bar 100 $\mu \mathrm{m}$.

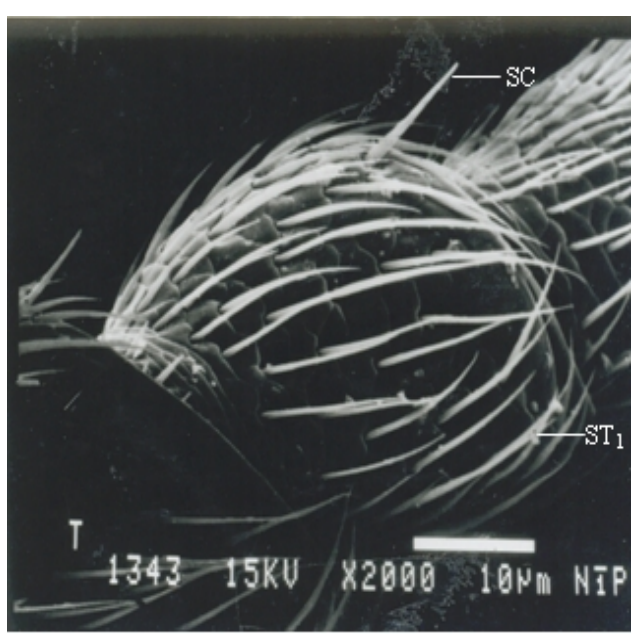

Fig. (4): SEM photomicrograph of treated adult of Callosobruchus maculatus with Lufenuron in scape region showing sensilla trichodea $\left(\mathrm{ST}_{1}\right)$ and sensilla chaetica (SC). Bar $100 \mu \mathrm{m}$. 


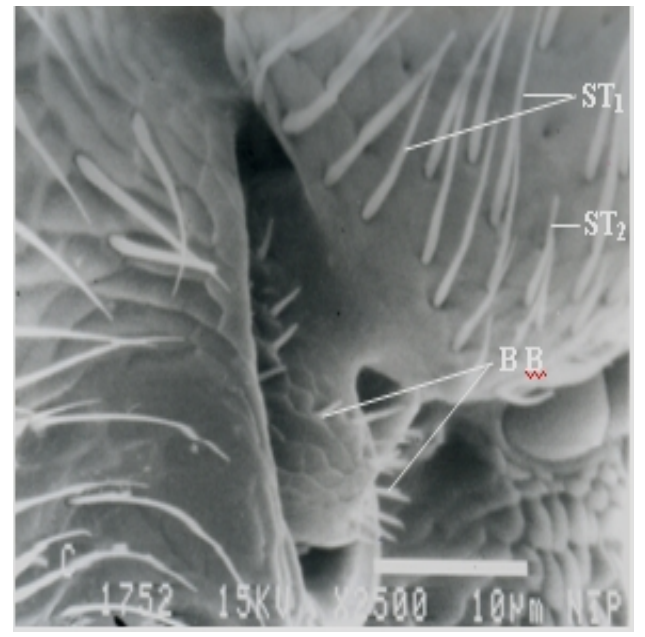

Fig. (5): SEM photomicrograph of untreated adult of Callosobruchus maculatus in pedicel region showing $\left(\mathrm{ST}_{1}, \mathrm{ST}_{2}\right)$ sensilla triochodea, Böhm bristles sensilla (BB) Bar $100 \mu \mathrm{m}$.

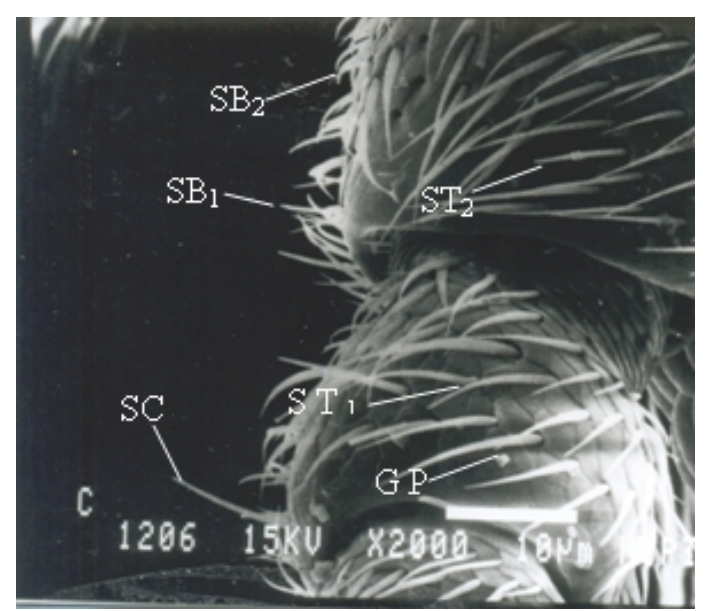

Fig. (7): SEM photomicrograph of untreated adult of Callosobruchus maculatus of flagellar segment showing sensilla trichodea $\left(\mathrm{ST}_{1}, \mathrm{ST}_{2}\right)$, grooved peg (GP) sensilla chaetica (SC) sensilla basicanica $\left(\mathrm{SB}_{1}, \mathrm{SB}_{2}\right)$. Bar $100 \mu \mathrm{m}$.

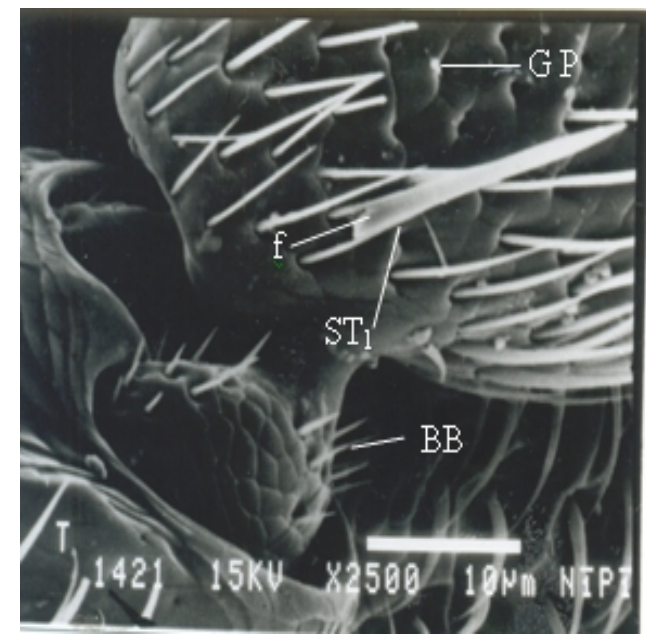

Fig. (6): SEM photomicrograph of treated adult of Callosobruchus maculatus with Lufenuron in pedicel region showing fusion (f) of sensilla trichodea $\left(\mathrm{ST}_{1}\right)$, Böhm bristle (BB) and grooved peg (GP). Bar $100 \mu \mathrm{m}$.

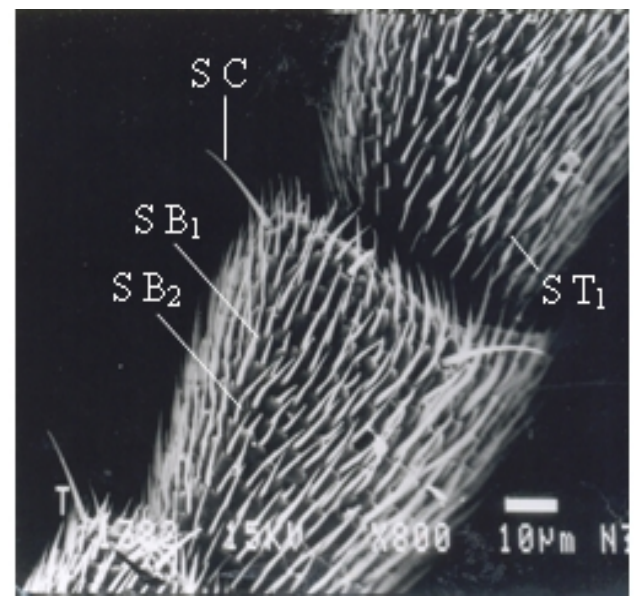

Fig. (8): SEM photomicrograph of treated adult of Callosobruchus maculates with Lufenuron of flagellar segment showing sensilla trichodea $\left(\mathrm{ST}_{1}\right)$, sensilla chaetica ( $\left.\mathrm{SC}\right)$ and sensilla Basiconica $\left(\mathrm{SB}_{1}, \mathrm{SB}_{2}\right)$. Bar 100 $\mu \mathrm{m}$. 


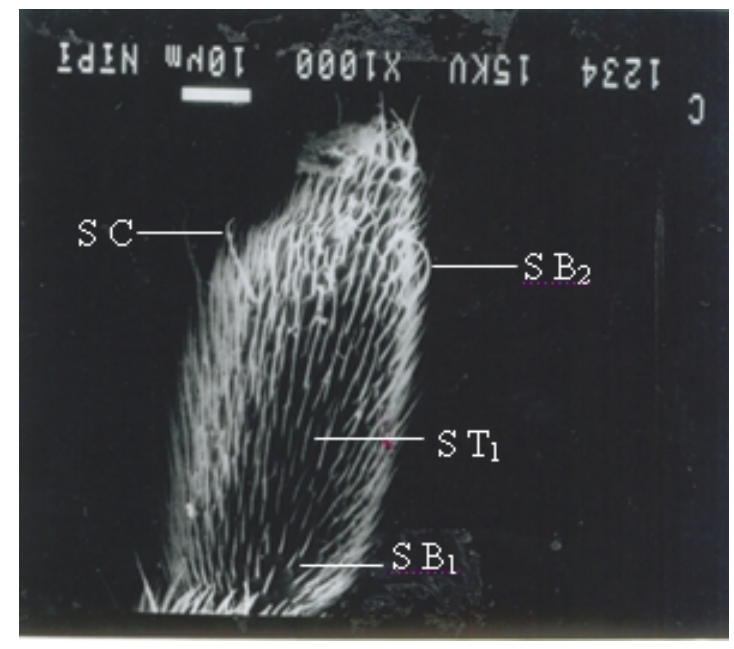

Fig. (9): SEM photomicrograph of untreated adult of Callosobruchus maculatus of last flagellar segment (9) showing sensilla trichodea $\left(\mathrm{ST}_{1}\right)$, sensilla chaetica $(\mathrm{SC})$ and sensilla Basiconica $\left(\mathrm{SB}_{1}, \mathrm{SB}_{2}\right)$. Bar $100 \mu \mathrm{m}$.

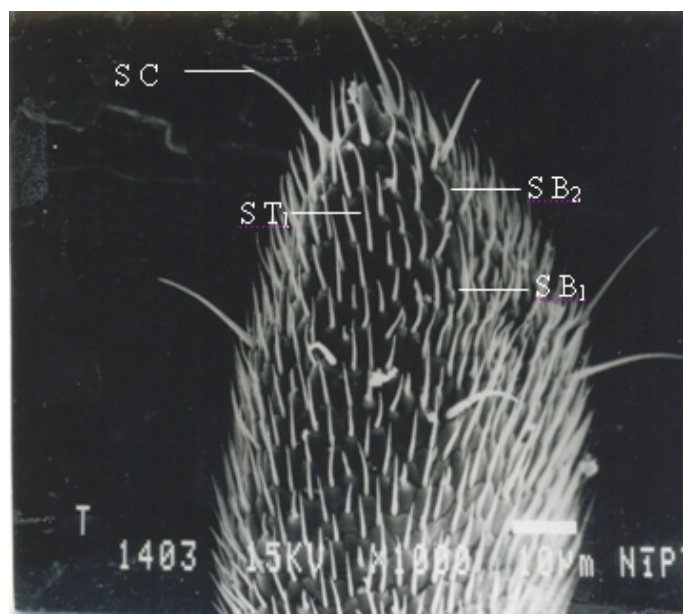

Fig. (10a): SEM photomicrograph of treated adult of Callosobruchus maculatus with Lufenuron in flagellar segments showing sensilla basiconica $\left(\mathrm{SB}_{1}, \mathrm{SB}_{2}\right)$. sensilla trichodea $\left(\mathrm{ST}_{1}\right)$ and sensilla chaetica (SC). Bar $100 \mu \mathrm{m}$.

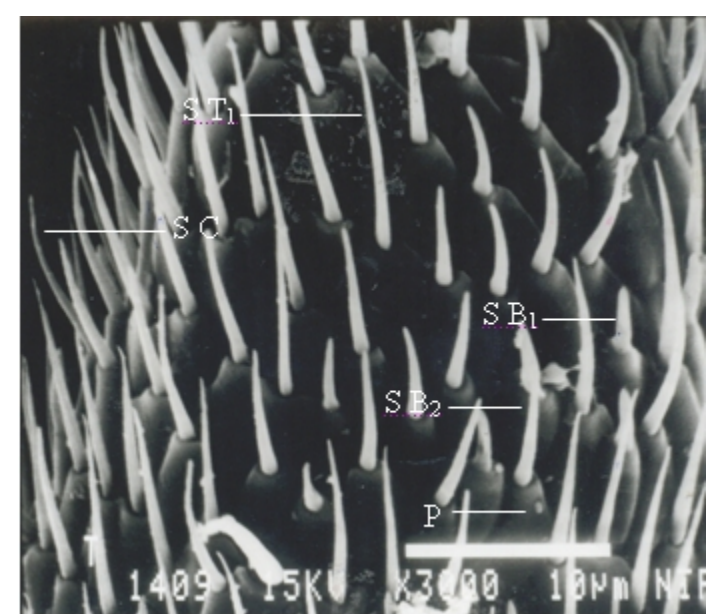

Fig.(10b): Higher magnification of photomicrograph of SEM of treated adult of Callosobruchus maculatus with Lufenuron in flagellar segments showing pores $(\mathrm{P})$ in sensilla basiconica $\quad\left(\mathrm{SB}_{2}\right)$. sensilla trichodea $\left(\mathrm{ST}_{1}\right)$, sensilla chaetica $(\mathrm{SC})$ and sensilla Basiconica $\left(\mathrm{SB}_{1}, \mathrm{SB}_{2}\right)$ Bar $100 \mu \mathrm{m}$. 


\section{ARABIC SUMMARY}

التغيرات المورفولوجيه المستحثه في قرون استثعار خنفساء اللوبيا كالوزوبروكس ماكيولاتس( فابريشيس) ( كوليوبترا: بروكيدى) بعد المعامله باللوفينرون.

ـ اليلى سيد حموده

- مليه العلوم - جامعه عين شمس لئل
سريا الطنطاوي حافظ - مري

استهذف البحث در اسه تأثثير مثبط النمو الكيتينى ( لوفينرون) على حلقات قرون الاستتشعار و شعبر اتها

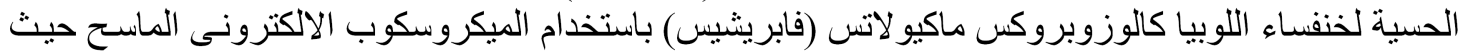

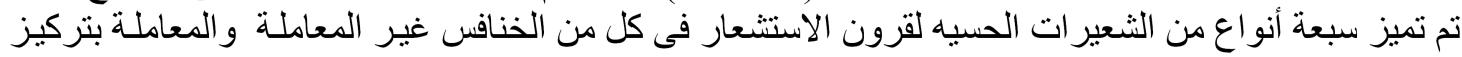

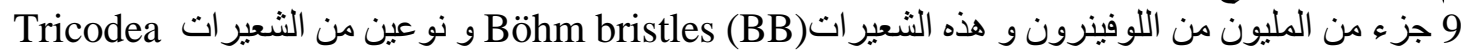

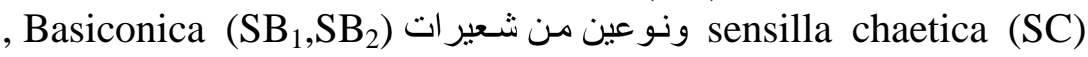
.groove peg (GP) ولقد تم مناقثنه وظائف هذة الشعير ات تبعا لموقعها على قرون الاستشعار.

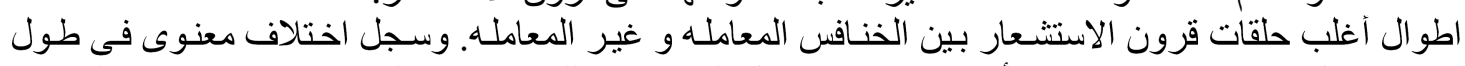
و عرض كل الانواع تقريبا. وكانت أكثر زيـادة فى طول الثنعير ات للثـعيرة من النوع (chaetica) ثم الثنعيرة

و هذه الانو اع تستخدم بو اسطة الحثـر ات كمستقبلات حسية ميكانيكية، مستقبلات للفرمونـات الخاصـة (Tricodea)

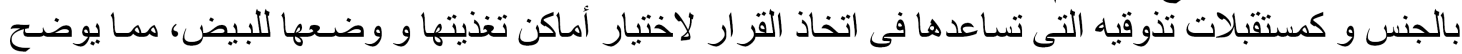
امكانية استخدام هذا المركب فى مكافحة هذه الآفة. 